\title{
Indeks sporozoit Anopheles spp. (Culicidae: Anophelinae) di daerah endemis malaria di Kecamatan Kokap, Kabupaten Kulon Progo
}

\author{
Sporozoite index of Anopheles spp. (Diptera: Anophelinae) in a malaria \\ endemic area of the Kokap Sub-district, Kulon Progo District
}

\author{
Andiyatu ${ }^{*}$, R.C. Hidayat Soesilohadi ${ }^{2}$, Niken Satuti Nur Handayani ${ }^{2}$, \\ Sukarti Moeljopawiro ${ }^{2}$
}

${ }^{1}$ Balai Besar Teknik Kesehatan Lingkungan dan Pengendalian Penyakit

Jalan Wiyoro Lor No. 21, Baturetno, Banguntapan, Bantul, Yogyakarta 55197

${ }^{2}$ Fakultas Biologi, Universitas Gadjah Mada, Jalan Teknika Selatan, Yogyakarta 55281

(diterima Oktober 2014, disetujui Desember 2014)

\begin{abstract}
ABSTRAK
Perbedaan endemisitas malaria antar desa dalam kecamatan yang sama mungkin berkaitan dengan perbedaan infektivitas dari Anopheles sp. Tujuan penelitian ini ialah untuk memeriksa proporsi spesies yang positif sporozoit atau infektivitas spesies (IS) dan proporsi sampel yang positif sporozoit atau indeks sporosoit total (IST) dari sebuah desa endemik tinggi (DET) dan sebuah desa endemik rendah (DER) di Kecamatan Kokap, Kabupaten Kulon Progro, Jawa Tengah. Empat spesies nyamuk Anopheles diperiksa, diantaranya Anopheles vagus Donitz, Anopheles maculatus (Theobald), Anopheles balabacensis Baisan, dan Anopheles aconitus Donitz. Nyamuk Anopheles sp. dikumpulkan secara serentak di dua desa, masing-masing lima kali selama Oktober-Desember 2013, dengan interval dua minggu, menggunakan metode resting collection. Pengumpulan nyamuk dilakukan setiap jam (@ 50 menit) di tiga rumah oleh dua kolektor per rumah (satu di dalam dan satu di luar), dari jam 18:00 sampai jam 06:00. Nyamuk betina parous diperiksa menggunakan metode Multiplex-PCR untuk mendeteksi keberadaan sporozoit. Pemeriksaan 77 sampel DNA menunjukkan bahwa IS dan IST kedua desa tersebut (49 DET dan 28 DER) berbeda nyata dengan rasio IS $66,7 \%$ : 33,3\% dan rasio IST $20,41 \%$ : $3,57 \%(\mathrm{OR}=6,9 ; \mathrm{CI} 95 \%=0,87$ sampai 57,$29 ; \mathrm{p}=0,021)$. Temuan ini mengindikasikan bahwa suatu transmisi malaria intensitas tinggi masih memungkinkan timbul di DET dan karenanya dibutuhkan suatu tindakan pengendalian vektor yang spesifik wilayah.
\end{abstract}

Kata kunci: Anopheles spp., endemisitas, indeks sporozoit, infektivitas

\begin{abstract}
Intervillage variation of malaria endemicity in the same sub-district is probably related to infectivity variation of Anopheles sp. The purpose of this research was to examine the proportion of sporozoite positive species, or species infectivity (SI), and the proportion of sporozoite positive samples, or total sporozoite index (TSI), of a high endemic village (HEV) and a low endemic village (LEV) in the Kokap Sub-District, Kulon Progro District, Central Java. Four Anopheline species were examined - Anopheles vagus Donitz, Anopheles maculatus (Theobald), Anopheles balabacensis Baisan, and Anopheles aconitus Donitz. Anopheles mosquitoes were concurrently collected in the two villages, five times each during October-December 2013, at two-week intervals, using the resting collection method. The mosquito collection was conducted every hour (50 minutes each) at three houses by two collectors each (one inside and one outside), from 18:00 PM to 06:00 AM. Female parous mosquitoes were examined using the Multiplex-PCR method to detect the presence of sporozoites. The examination of 77 DNA samples showed that the SI and TSI of the two villages (49 HEV and $28 \mathrm{LEV}$ ) were significantly

\footnotetext{
*Penulis korespondensi: Andiyatu. Balai Besar Teknik Kesehatan Lingkungan dan Pengendalian Penyakit, Jalan Wiyoro Lor No. 21, Baturetno, Banguntapan, Bantul, Yogyakarta 55197, Tel: (0274) 371588, Faks: (0274) 443284, Email: andyatu@yahoo.com.
} 
different: a SI ratio of $66,7 \%: 33,3 \%$ and a TSI ratio of $20,41 \%: 3,57 \%(\mathrm{OR}=6,9 ; \mathrm{CI} 95 \%=0.87$ to $57.29 ; \mathrm{p}=0.021)$. This finding indicates that a high intensity malaria transmission could occur in the HEV and that a specific vector control measure is necessary.

Key words: Anopheles spp, endemicity, infectivity, sporozoite index

\section{PENDAHULUAN}

Di dunia terdapat kurang lebih 430 spesies nyamuk anggota Genus Anopheles, namun hanya 70 spesies dinyatakan kompeten vektor malaria (Snow \& Gilles 2002). Di Indonesia, dari 81 Anopheles sp. yang ada terdapat 25 spesies yang telah dikonfirmasi sebagai vektor malaria (Kirnowardoyo et al. 2007; Asik et al. 2014). Status kompetensi vektor Anopheles sp. di suatu wilayah penting ditetapkan karena tidak semua spesies kompeten sebagai vektor malaria. Kompetensi vektor dapat berbeda antar maupun intra spesies, yaitu spesies yang sama, tetapi wilayah berbeda. Perbedaan kompetensi vektor antar dan intra spesies Anopheles disebabkan oleh perbedaan faktor bionomik populasi, mencakup tingkat kerentanan terhadap Plasmodium, rentang umur (longevity), sifat antropofilik, dan kepadatan relatif/kelimpahan nisbi (Mardihusodo 1999; Boewono 2012).

Informasi keberadaan spesies kompeten vektor dan karakteristik bionomiknya sangat diperlukan dalam memahami epidemiologi dan penentuan strategi penanggulangan penyakit tular vektor, termasuk malaria (Sigit 2005). Bagi wilayah endemis malaria, terutama wilayah yang akan memasuki tahap eliminasi, sangat diperlukan ketersediaan informasi sebaran Anopheles sp. kompeten vektor dan besaran infektifitas (Indeks Sporozoit) di tingkat spesies maupun tingkat wilayah (total spesies). Kedua informasi entomologis tersebut sangat membantu pemangku kepentingan (stakeholder) di dalam memahami epidemiologis penyakit dan penyusunan skala prioritas upaya pengendalian vektor secara tepat sasaran.

Kulon Progo merupakan satu-satunya kabupaten yang belum mencapai eliminasi malaria di Provinsi Daerah Istimewa Yogyakarta (DIY). Pada tahun 2012 status eliminasi malaria di Kabupaten Kulon Progo berada dalam fase praeliminasi, ditandai dengan capaian annual parasite incidence (API) $<1 \%$. Di kabupaten ini masih terdapat tiga kecamatan endemis malaria di daerah perbukitan Bukit Menoreh (Kokap, Girimulyo, dan Samigaluh). Kokap tercatat sebagai kecamatan dengan jumlah kasus malaria tertinggi (API 4,8\%). Kasus malaria di Kecamatan Kokap tahun 2012 berkontribusi $67,5 \%$ terhadap total (237) kasus malaria di Kabupaten Kulon Progo (Dinkes. Kab. Kulon Progo 2012).

Kecamatan Kokap memiliki lima desa, yaitu Kalirejo, Hargorejo, Hargomulyo, Hargotirto, dan Hargowilis. Meskipun berada dalam wilayah kecamatan sama, kelima desa tersebut memiliki perbedaan endemisitas malaria. Laporan Murhandarwati et al. (2014) menunjukkan tingkat endemis malaria di lima desa tersebut bervariasi berdasarkan API, yaitu dua desa tergolong endemis tinggi (Kalirejo dan Hargotirto), satu desa endemis sedang (Hargowilis), dan dua desa endemis rendah (Hargorejo dan Hargomulyo). Penentuan status endemisitas malaria di lima desa tersebut didasarkan atas kriteria dalam Kemenkes. (2011) bahwa endemisitas dibagi atas tiga strata, yaitu endemis rendah, sedang, dan tinggi, dengan besaran API secara berurut $<1,1-5$, dan $>5 \%$.

Endemisitas malaria suatu wilayah dipengaruhi berbagai faktor, antara lain infektifitas nyamuk vektor, yaitu banyaknya anggota populasi Anopheles sp. vektor yang terinfeksi sporozoit Plasmodium sp. (Snow \& Gilles 2002). Untuk mempelajari fenomena endemisitas malaria yang berbeda antar desa di Kecamatan Kokap maka dilakukan pengukuran indeks sporozoit populasi Anopheles sp. di dua desa berbeda endemisitas, yaitu satu desa endemis tinggi dan satu desa endemis rendah.

Tujuan penelitian adalah mengetahui infektifitas spesies (proporsi spesies yang terinfeksi sporozoit) dan indeks sporozoit (proporsi sampel DNA nyamuk Anopheles sp. positif sporozoit) di DET dan DER di Kecamatan Kokap, Kabupaten Kulon Progo. Pengukuran indeks sporozoit Anopheles sp. antar wilayah bermanfaat dalam memberikan informasi entomologis penting tentang status kompetensi vektor Anopheles sp., yaitu spesies yang berperan penting dalam penularan malaria (Mahapatra et al. 2006). Informasi ini sangat diperlukan dalam perencanaan intervensi maupun untuk evaluasi efektifitas intervensi yang telah dilakukan (Msugh-Ter et al. 2014). 


\section{BAHAN DAN METODE}

\section{Objek penelitian}

Objek penelitian adalah Anopheles vagus Donitz, Anopheles aconitus Donitz, Anopheles maculatus (Theobald), dan Anopheles balabacensis Baisan, yakni spesies dinyatakan suspect/vektor malaria pada penelitian sebelumnya. Keempat spesies tersebut ditemukan positif sircumsporozoite-protein (CSP) Plasmodium falciparum dan Plasmodium vivax, misalnya An. aconitus di Kabupaten Magelang dan Pekalongan (Widyastuti 2001; Barodji et al. 2007; Bangs \& Rusmiarto 2007), An. balabacensis di Kecamatan Kokap, Magelang, dan Purworejo (Adrial et al. 2000; Bangs \& Rusmiarto 2007), An. maculatus di Kecamatan Kokap, Purworejo, dan Banjarmangu (Widyastuti et al. 2013; Bangs \& Rusmiarto 2007); dan An. vagus di Kokap, Purworejo, dan NTT (Wigati et al. 2006; 2010; Theodolfi 2011).

\section{Lokasi penelitian}

Penelitian dilaksanakan di Desa Hargotirto dan Hargomulyo Kecamatan Kokap Kabupaten Kulon Progo, terletak di daerah perbukitan Bukit Menoreh dengan ketinggian $\pm 100 \mathrm{~m}$ dpl (BPS Kulon Progo 2012). Kedua lokasi dipilih berdasarkan perbedaan endemisitas malaria, yaitu Hargotirto sebagai desa endemis tinggi (DET) dan Hargomulyo sebagai desa endemis rendah (DER) malaria. Jarak antara kedua desa $\pm 7-8 \mathrm{~km}$. Luas wilayah DET dan DER tidak jauh berbeda (rasio 1.471,73:1.520,97 ha) dengan rasio jumlah penduduk $4.788: 8.011$ jiwa. Keberadaan ternak (sapi) lebih rendah jumlahnya di DET dibanding DER, dengan rasio 124 : 675 ekor (Kecamatan Kokap 2013).

\section{Pengambilan sampel nyamuk}

Pengambilan sampel nyamuk menggunakan metoda resting collection (RC), yakni menangkap nyamuk beristirahat di dalam dan di luar rumah. Metoda RC dipilih karena alasan (1) memiliki risiko rendah terjadinya gigitan nyamuk infektif pada penangkap nyamuk bila dibandingkan dengan metode umpan badan manusia (Service \& Townson 2002), dan (2) representatif untuk berbagai tujuan pemeriksaan, misalnya pengukuran tingkat kepadatan, status paritas (rentang umur), dan status blood meal.
Pengumpulan sampel nyamuk di DET dan DER masing-masing dilakukan 5 kali antara OktoberDesember 2013. Penangkapan nyamuk di tiap desa dilakukan di tiga rumah oleh dua orang penangkap per rumah (satu di dalam dan satu di luar rumah/ di kandang ternak). Tiga rumah dipilih di DET terdiri atas satu rumah terdapat penderita malaria (satu bulan terakhir sebelum penangkapan) dan dua rumah terdekat di sekitarnya. Di DER (tidak terdapat penderita selama periode penangkapan) dipilih tiga rumah berlokasi tidak jauh dari tempat perindukan nyamuk $(<2 \mathrm{~km})$ sehingga memungkinkan memperoleh sampel nyamuk.

Nyamuk yang beristirahat di dalam rumah (di dinding, gantungan pakaian, kelambu/gorden, atau di bawah perabot) dan di luar rumah (di kandang sapi dan semak di halaman) ditangkap menggunakan aspirator mekanis. Penangkapan nyamuk dilaksanakan sebanyak12 kali (@50 menit per jam), mulai pukul 18:00 sampai 06:00. Nyamuk tertangkap dimasukkan ke paper cup terpisah menurut jam. Setiap nyamuk ditentukan spesiesnya berdasarkan Kunci Identifikasi Nyamuk Anopheles Dewasa (O'Connor \& Soepanto 1999; Depkes. 2000; Reid 1968). Status paritas Anopheles sp. sasaran (parous atau nulliparous) ditentukan berdasarkan hasil pemeriksaan ovarium di bawah lensa objektif mikroskop perbesaran 10 dan 40 kali. Prosedur pemeriksaan ovarium sesuai pedoman dalam Service \& Townson (2002) dan Depkes. (2003). Nyamuk dinyatakan parous (pernah bertelur/berumur dewasa) bila ujung tracheola ovarium tampak membuka/terburai, sedangkan nulliparous (belum pernah bertelur/ berumur muda) bila ujung tracheola masih menggulung. Khusus nyamuk parous diambil bagian kepala dan toraksnya lalu dimasukkan ke tabung eppendorf terpisah dan disimpan dalam toples berisi silica gel. Selanjutnya sampel kepala dan toraks dibawa ke laboratorium untuk proses isolasi DNA.

\section{Ekstraksi DNA}

Bahan dasar ekstraksi DNA pada sampel nyamuk hanya menggunakan bagian kepala dan toraks. Hal ini dimaksudkan agar Plasmodium yang terdeteksi adalah Plasmodium tahap sporozoit (Bass et al. 2008). Prosedur ekstraksi mengikuti protokol GenJet Genomic DNA Purification Kit 
(Thermo Scientific), kecuali pemakaian Proteinase K dikurangi separuh $(10 \mu \mathrm{l})$ dari protokol $(20 \mu \mathrm{l})$. Pengurangan ini dilakukan dengan pertimbangan bahwa Proteinase K $20 \mu$ diperuntukkan bagi $20 \mathrm{mg}$ sampel jaringan mamalia, sedangkan berat 20 organ kepala dan toraks nyamuk tidak $>10 \mathrm{mg}$. Ekstraksi DNA menggunakan sistim individu (satu pool berisi satu organ kepala dan toraks dari satu individu nyamuk-bagi spesies memiliki anggota $<10$ individu) dan komposit (satu pool berisi minimal 2 dan maksimal 20 organ kepala dan toraks dari spesies sama-bagi spesies memiliki anggota $>10$ individu). Kedua sistim ekstraksi tersebut menggunakan prosedur dan komponen sama, seperti dalam protokol GenJet Genomic DNA Purification Kit (Thermo Scientific). DNA hasil purifikasi disimpan pada suhu $-20{ }^{\circ} \mathrm{C}$ apabila tidak segera diproses untuk analisis selanjutnya.

\section{Primer}

Primer untuk deteksi sporozoit Plasmodium sp. di sampel DNA nyamuk mengacu Patsoula et al. (2003), terdiri atas tiga jenis, yaitu (1) PL3 (5'-ATG GCC GTT TTT AGT TCG TG-3'); (2) PL4 (5'GGA AAC GGT ACG ATA AGC CA-3'); dan (3) PL5 (5'-ACG CGT GCA GCC TAG TTT AT-3'), diproduksi oleh MWG Biotech (High Point, NC). Primer tersebut didesain berdasarkan sekuens gen small-subunit ribosomal RNA (ssu-rRNA) P. vivax dan $P$. falciparum pada database GenBank dengan accession numbers (AN) U03080 dan M19173. Primer PL3 mengamplifikasi sekuens yang umum untuk gen rRNA $P$. falciparum (nukleotida 1390-1409, AN U03080) dan P. vivax (nukleotida 1427-1446, AN M19173), sedangkan PL4 dan PL5, masing-masing sebagai primer spesifik $P$. vivax (nukleotida 1636-1655, AN U03080) dan $P$. falciparum (nukleotida 1753-1772, AN M19173). Dengan aplikasi metoda single step (multiplexPCR), primer PL3 bersama PL4 dihasilkan produk spesifik $266 \mathrm{pb}$ untuk $P$. vivax, sedangkan dengan primer PL3 dan PL5 dihasilkan produk spesifik 346 pb untuk $P$. falciparum (Patsoula et al. 2003).

\section{Amplifikasi DNA}

Komposisi reaksi PCR untuk amplifikasi DNA Plasmodium sp. pada sampel DNA genom nyamuk adalah seperempat (25 $\mu$ l) dari volume akhir (100 $\mu 1)$ dalam Patsoula et al. (2002), terdiri atas 12,5 $\mu 1$ mix PCR, 4,5 $\mu \mathrm{lddH_{2 }} \mathrm{O}, 1 \mu \mathrm{l}$ untuk masing-masing primer (PL3, PL5, dan PL5), dan $5 \mu$ template DNA. Dalam uji PCR digunakan kontrol positif (P. falciparum 3D7) dari Laboratorium Biologi Molekular Eijkman Jakarta dan kontrol negatif (nyamuk Anopheles tidak terinfeksi Plasmodium sp.) dari Laboratorium Balai Besar Penelitian dan Pengembangan Vektor dan Reservoar Penyakit (BBPPVRP) Salatiga. Kondisi optimum untuk amplifikasi DNA Plasmodium adalah predenaturasi 5 menit pada suhu $94{ }^{\circ} \mathrm{C}$; denaturasi, annealing dan ekstensi masing-masing $94{ }^{\circ} \mathrm{C}, 55,5^{\circ} \mathrm{C}$, dan $72{ }^{\circ} \mathrm{C}$ dengan lama waktu masing-masing 30 detik; dan elongasi 10 menit pada suhu $72{ }^{\circ} \mathrm{C}$, dengan jumlah siklus 40 kali.

\section{Elektroforesis dan visualisasi hasil}

Penentuan sampel nyamuk positif sporozoit Plasmodium sp. didasarkan hasil elektroforesis, yang menggunakan agarosa $2 \%$ dan ethidium bromida. Elektroforesis dilakukan dengan memasukkan $5 \mu 1$ produk PCR ke dalam sumuran, kecuali sumuran 1 dimasukkan $3 \mu 1$ DNA ladder sebagai marker (100-1500 pb). Proses running elektroforesis berlangsung 60 menit dengan 80 volt. Hasil elektroforesis diamati dengan UV transilluminator untuk melihat kemunculan pita DNA. Dalam penelitian ini digunakan kontrol positif untuk P. falciparum (346 pb). Kemunculan pita DNA yang sejajar dengan pita DNA kontrol positif maka sampel tersebut dinyatakan positif mengandung sporozoit P. falciparum. Sebaliknya, bila posisi pita DNA $<346 \mathrm{pb}$ maka sampel tersebut dipastikan positif $P$. vivax (266 pb) karena primer yang digunakan hanya spesifik mengamplifikasi pita DNA $346 \mathrm{pb}$ - untuk $P$. falciparum dan 266 pb-untuk P. vivax (Patsoula et al. 2003).

\section{Analisis data}

Infektifitas spesies (IS) Anopheles sp. adalah proporsi (persentase) spesies positif sporozoit dari jumlah spesies yang diuji PCR, sedangkan indeks sporozoit menurut spesies (proporsi sampel positif dari spesies tertentu menurut wilayah) dan indeks sporozoit total (IST) wilayah (proporsi sampel positif dari keseluruhan spesies menurut wilayah) ditentukan secara kuantitatif menggunakan rumus sebagai berikut:

$$
\text { Indeks sporozoit }=\frac{\begin{array}{c}
\text { Jumlah sampel nyamuk positif } \\
\text { sporozoit (spesies tertentu })
\end{array}}{\begin{array}{c}
\text { Total sampel nyamuk diperiksa } \\
\text { (dari spesies yang sama) }
\end{array}} \times 100
$$


Keberadaan sporozoit Plasmodium sp. pada anggota populasi Anopheles menunjukkan secara kualitatif bahwa spesies tersebut kompeten sebagai vektor malaria (Boewono 2012). Analisis IS antar spesies dilakukan secara deskriptif berdasarkan besaran nilai IS per spesies per wilayah.

Pengujian perbedaan infektifitas Anopheles sp. di DET dan DER dilakukan dengan perangkat lunak Open-Epi versi 2.2 menggunakan ukuran odds ratio (OR), yaitu salah satu ukuran dalam studi epidemiologi (kasus kontrol, potong lintang, kohor, maupun eksperimental) untuk menunjukkan perbedaan risiko dari dua populasi yang dibandingkan (Murti 2013). Interpretasi nilai OR mengacu kriteria dalam Szumilas (2010), yaitu $\mathrm{OR}=1$ (tidak ada perbedaan) dan $\mathrm{OR}=>1$ (ada perbedaan). Penilaian besar perbedaan mengacu kriteria effect size dalam Wilson (2011), yaitu perbedaan kecil $(\mathrm{OR}<2,5)$, sedang (OR 2,5-4,2), dan besar $(\mathrm{OR} \geq 4,3)$.

\section{HASIL}

\section{Keanekaragaman dan komposisi spesies}

Spesies nyamuk Anopheles tertangkap di Desa Hargotirto (DET) dan Hargomulyo (DER) Kecamatan Kokap selama penelitian seluruhnya berjumlah 10 spesies (Tabel 1).
Keanekaragaman spesies Anopheles DET lebih rendah dibandingkan dengan DER (rasio $6: 9$ ). Meskipun keanekaragaman spesies lebih rendah, DET memiliki proporsi spesies suspect/vektor malaria yang lebih tinggi $(66,7 \% ; n=4 / 6)$. Empat spesies suspect/vektor malaria (An. aconitus, An. balabacensis, An. maculatus, dan An. vagus) lengkap ditemukan di DET. Sebaliknya, DER yang memiliki keanekaragaman spesies lebih tinggi (9 spesies), hanya ditemukan tiga $(33,3 \%)$ spesies suspect/vektor malaria (An. aconitus, An. maculatus, dan An. vagus).

\section{Karakteristik bionomik populasi Anopheles sp.}

Gambaran karakteristik bionomik populasi Anopheles sp. DET dan DER dilihat dari faktor kelimpahan nisbi (Kn) dan Indeks Parous (IP). DET memiliki lebih banyak (tiga) spesies yang terdapat dalam kelimpahan tinggi $(\mathrm{Kn}>5 \%)$, terdiri atas An.vagus $(\mathrm{Kn}=63,33 \%)$, An. maculatus $(\mathrm{Kn}$ $=29,17 \%)$ dan An. balabacensis $(\mathrm{Kn}=6,67 \%)$. Di DER hanya terdapat satu spesies memiliki Kn tinggi, yaitu An. vagus ( $\mathrm{Kn}=98,05 \%)($ Tabel 2).

Nilai rata-rata IP Anopheles di DET lebih tinggi (IP $=71,9 \%$; kisaran IP $=67,1-75,0 \%)$. Nilai rata-rata IP Anopheles sp. DER 64,0\% (kisaran IP $=48,3-76,9 \%$ ). IP rata-rata Anopheles sp. di DET yang lebih tinggi mengindikasikan rentang umur Anopheles di DET lebih tinggi dari DER.

Tabel 1. Jenis spesies dan status kompetensi vektoral (KV) Anopheles spp. tertangkap di desa endemis tinggi (Hargotirto) dan desa endemis rendah malaria (Hargomulyo) di Kecamatan Kokap, OktoberDesember 2013

\begin{tabular}{lcccc}
\hline \multirow{2}{*}{ Spesies } & \multicolumn{2}{c}{$\begin{array}{c}\text { Desa endemis tinggi } \\
\text { (Hargotirto) }\end{array}$} & \multicolumn{2}{c}{$\begin{array}{c}\text { Desa endemis rendah } \\
\text { (Hargomulyo) }\end{array}$} \\
\cline { 2 - 5 } & $\mathrm{n}(\%)$ & Status KV* & $\mathrm{n}(\%)$ & Status KV* \\
\hline Anopheles aconitus & $1(0,71)$ & Vektor & $3(0,35)$ & Vektor \\
An. annularis & $4(2,86)$ & Non vektor & $7(0,80)$ & Non vektor \\
An. balabacensis & $8(5,71)$ & Vektor & $0(0,00)$ & \\
An. barbirostris & $0(0,00)$ & & $1(0,12)$ & Non vektor \\
An. flavirostris & $16(11,43)$ & Non vektor & $28(3,22)$ & Non vektor \\
An. kochi & $0(0,00)$ & & $1(0,12)$ & Non vektor \\
An. maculatus & $35(25,00)$ & Vektor & $13(1,49)$ & Vektor \\
An. subpictus & $0(0,00)$ & & $10(1,15)$ & Non vektor \\
An. tesselatus & $0(0,00)$ & & $2(0,23)$ & Non vektor \\
An. vagus & $76(54,29)$ & Suspect & $804(92,52)$ & Suspect \\
\hline Jumlah & $140(100)$ & & $869(100)$ & \\
\hline
\end{tabular}

*Status kevektoran berdasarkan penelitian sebelumnya. 
IP tertinggi di DET ditempati An. balabacensis (75,0\%), disusul An. maculatus (73,5\%) dan An. vagus $(67,1 \%)$. Di DER, IP tertinggi dimiliki $A n$. maculatus (76,9\%), diikuti An. aconitus (66,7\%) dan terendah An. vagus (48,4\%) (Tabel 2).

\section{Indeks sporozoit Anopheles sp.}

Ekstraksi DNA dengan sistem individu dan komposit pada 82 nyamuk parous DET dan 401 nyamuk parous DER dihasilkan 77 sampel DNA-49 dari DET dan 28 dari DER. Pemeriksaan 77 sampel DNA tersebut ditemukan 11 sampel positif sporozoit-10 sampel DET dan 1 sampel DER. Spesies Plasmodium yang menginfeksi nyamuk semuanya berasal dari $P$. vivax, ditandai dengan kemunculan pita DNA 266 pb pada gel elektroforesis (Gambar 1).

Terdapat tiga spesies positif sporozoit, yaitu dua di DET (An. maculatus dan An. vagus) dan satu di DER (An. aconitus) (Tabel 3). Temuan ini menunjukkan infektifitas spesies (proporsi spesies Anopheles positif sporozoit) lebih tinggi di DET dibandingkan dengan DER (rasio 66,67\% : 33,3\%). IS tertinggi di DET ditemukan di An. maculatus (28\%; $\mathrm{n}=32)$, disusul oleh An. vagus $\quad(16,67 \%$; $\mathrm{n}$ $=21)$. Di DER, diperoleh IS An. aconitus sebesar $100 \%(\mathrm{n}=1)$.

Infektifitas di tingkat individu Anopheles juga lebih tinggi di DET (Tabel 3). Secara total wilayah, indeks sporozoit di DET lebih tinggi secara bermakna, ditunjukkan rasio IST sebesar $20,4 \%: 3,57 \%$ dengan OR 6,92 (CI95\% $=0,87$ hingga 57,$29 ; \mathrm{p}=0,021)$. Nilai $\mathrm{OR}$ tersebut menggambarkan besar risiko anggota populasi Anopheles sp. DET untuk terinfeksi sporozoit $P$. vivax adalah 7 kali lebih dari populasi Anopheles sp. DER.

Tabel 2. Kelimpahan nisbi dan Indeks Parous populasi Anopheles spp. di desa endemis tinggi (Hargotirto) dan desa endemis rendah (Hargomulyo) di Kecamatan Kokap selama Oktober-Desember 2013

\begin{tabular}{lcccccc}
\hline & \multicolumn{3}{c}{ Desa endemis malaria tinggi (Hargotirto) } & \multicolumn{2}{c}{ Desa endemis malaria rendah (Hargomulyo) } \\
\cline { 2 - 7 } Spesies & $\begin{array}{c}\text { Jumlah } \\
\text { nyamuk } \\
\text { tertangkap } \\
(\mathrm{n})\end{array}$ & $\begin{array}{c}\text { Kelimpahan } \\
\text { nisbi (\%) }\end{array}$ & $\begin{array}{c}\text { Jumlah nyamuk } \\
\text { parous } \\
\text { (Indeks Parous) }\end{array}$ & $\begin{array}{c}\text { Jumlah } \\
\text { nyamuk } \\
\text { tertangkap } \\
\text { (n) }\end{array}$ & $\begin{array}{c}\text { Kelimpahan } \\
\text { nisbi (\%) }\end{array}$ & $\begin{array}{c}\text { Jumlah nyamuk } \\
\text { parous } \\
\text { (Indeks Parous) }\end{array}$ \\
\hline Anopheles aconitus & 1 & 0,83 & $0(0,00)$ & 3 & 0,37 & $2(66,67)$ \\
An. balabacensis & 8 & 6,67 & $6(75,00)$ & 0 & 0 & 0 \\
An. maculatus & 35 & 29,17 & $25(73,53)$ & 13 & 1,58 & $10(76,92)$ \\
An. vagus & 76 & 63,33 & $51(67,11)$ & 804 & 98,05 & $389(48,26)$ \\
\hline Total & 120 & 100,00 & $82(68,91)$ & 820 & 100,00 & $401(48,78)$ \\
\hline
\end{tabular}
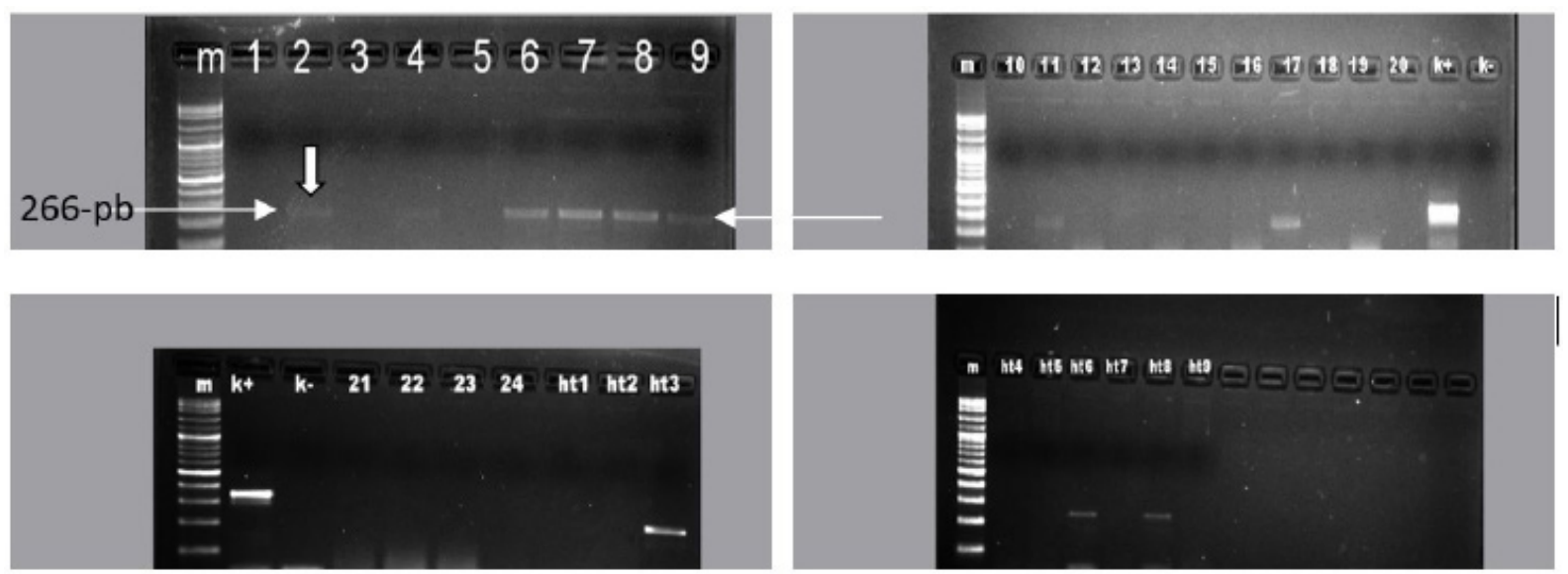

Gambar 1. Visualisasi pita DNA (266 pb) hasil elektroforesis yang menunjukkan sampel nyamuk Anopheles spp. uji positif Plasmodium vivax dari Desa Hargotirto dan Desa Hargomulyo, Kecamatan Kokap. Kode sampel 2, 4, 6, 7, 8, 9 dan 11: An. maculatus di Hargotirto); 17: An. aconitus di Hargomulyo); ht3, ht6, dan ht8: An. vagus di Hargotirto; m: ladder DNA 100-1500 pb; k+: kontrol positif $P$. falciparum 346- pb; dan k-: kontrol negatif. 
Tabel 3. Angka sporozoit Anopheles spp. uji pada daerah endemis malaria tinggi (Hargotirto) dan desa endemis malaria rendah (Hargomulyo) di Kecamatan Kokap selama Oktober-Desember 2013

\begin{tabular}{lcccccc}
\hline & \multicolumn{3}{c}{ Desa endemis malaria tinggi } & \multicolumn{2}{c}{ Desa endemis malaria rendah } \\
\cline { 2 - 7 } Spesies & $\begin{array}{c}\text { Jumlah } \\
\text { sampel } \\
\text { uji (n) }\end{array}$ & $\begin{array}{c}\text { Jumlah positif } \\
\text { Plasmodium }\end{array}$ & $\begin{array}{c}\text { Angka } \\
\text { sporozoit } \\
(\%)\end{array}$ & $\begin{array}{c}\text { Jumlah } \\
\text { sampel } \\
\text { uji (n) }\end{array}$ & $\begin{array}{c}\text { Jumlah positif } \\
\text { Plasmodium }\end{array}$ & $\begin{array}{c}\text { Angka } \\
\text { sporozoit } \\
(\%)\end{array}$ \\
\hline Anopheles aconitus & 0 & 0 & 0,00 & 1 & 1 & 100,00 \\
An. balabacensis & 6 & 0 & 0,00 & 0 & 0 & 0,00 \\
An. maculatus & 25 & 7 & 28 & 7 & 0 & 0,00 \\
An. vagus & 18 & 3 & 16,67 & 20 & 0 & 0,00 \\
\hline Total & 49 & 10 & 20,41 & 28 & 1 & 3,57 \\
\hline OR & 10 & & & & & 0 \\
\hline
\end{tabular}

$\mathrm{OR}=6,9(\mathrm{CI} 95 \%=0,87-57,29 ; \mathrm{p}=0,021)$

OR: odds ratio.

\section{PEMBAHASAN}

Dari kajian indeks sporozoit di dua desa berbeda endemisitas di Kecamatan Kokap, yaitu Desa Hargotirto (desa endemis tinggi) dan Desa Hargomulyo (desa endemis rendah) malaria, dihasilkan dua informasi penting. Pertama, di Desa Hargotirto ditemukan lebih banyak spesies kompeten vektor malaria untuk $P$. vivax, yaitu An. maculatus dan An. vagus, sedangkan di Desa Hargomulyo hanya satu spesies kompeten vektor malaria $P$. vivax, yaitu An. aconitus. Ketiganya dinyatakan kompeten vektor karena di masingmasing spesies tersebut ditemukan sporozoit $P$. vivax. Sebagaimana menurut Boewono (2012) bahwa secara kualitatif kompetensi vektoral suatu spesies ditentukan berdasarkan penemuan sporozoit atau circum sporozoite protein dalam kelenjar ludah nyamuk (kepala dan toraks). Kedua, di Desa Hargotirto ditemukan lebih banyak anggota populasi Anopheles sp. positif sporozoit P. vivax, dengan rasio indeks sporozoit $20,4 \%$ : $3,57 \%$. Kedua informasi tersebut menggambarkan bahwa Anopheles sp. di Desa Hargotirto memiliki infektifitas lebih tinggi, baik di tingkat spesies (proporsi spesies positif sporozoit) maupun di tingkat individu Anopheles sp. Temuan ini sejalan dengan teori bahwa tingkat endemis malaria suatu wilayah dipengaruhi oleh faktor, antara lain infektifitas nyamuk vektor-seberapa banyak/ tinggi infeksi Plasmodium sp. terjadi di nyamuk vektor (Service \& Townson 2002). Intensitas penularan malaria yang tinggi (endemis tinggi) di Desa Hargotirto adalah berkaitan dengan proporsi spesies kompeten vektor dan anggota populasi terinfeksi sporozoit $P$. vivax yang lebih tinggi di wilayah setempat.

Sporozoit $P$. vivax hanya ditemukan di populasi An. maculatus dan An. vagus di Desa Hargotirto, tidak populasi di Desa Hargomulyo. Kondisi ini menunjukkan ada perbedaan kompetensi vektoral intra spesies An. maculatus maupun An. vagus, dalam arti kemampuan menularkan Plasmodium sp. (penyakit malaria) hanya ada di populasi $A n$. maculatus maupun An. vagus di Desa Hargotirto. Perbedaan kompetensi vektoral intra spesies tersebut terkait dengan perbedaan karakteritik bionomik antar populasi, misalnya dalam hal rentang umur, kelimpahan, atau sifat antropofilik (Mardihusodo 1999; Boewono 2012). Populasi An. maculatus dan An. vagus Hargotirto yang ditemukan positif sporozoit $P$. vivax, keduanya memiliki rentang umur panjang (IP $>50 \%$ ) dan kelimpahan tinggi $(\mathrm{Kn}>5 \%)$. Kedua ciri tersebut tidak ditemukan lengkap di populasi $A n$. maculatus dan An. vagus di Desa Hargomulyo. Populasi An. maculatus di Desa Hargomulyo juga memiliki rentang umur panjang (IP $>50 \%$ ), tetapi kelimpahannya rendah $(\mathrm{Kn}<5 \%)$, sedangkan populasi An. vagus adalah sebaliknya, yaitu terdapat dalam kelimpahan tinggi $(\mathrm{Kn}>$ $5 \%)$ atau bahkan sangat tinggi $(\mathrm{Kn}>15 \%)$, tetapi rentang umur populasi relatif pendek (IP $<50 \%$ ). Pengecualian terjadi di populasi An. aconitus di Desa Hargomulyo, yaitu meski populasi terdapat dalam kelimpahan rendah atau bahkan sangat rendah $(\mathrm{Kn}<1 \%)$, tetapi positif sporozoit $P$. vivax. Hal ini menunjukkan kelimpahan bukan faktor penentu utama kompetensi vektoral. Penjelasan tentang fenomena An. aconitus yang dalam 
kelimpahan populasi sangat rendah, tetapi positif sporozoit adalah terkait dengan strategi populasi dalam pencarian darah, yaitu dilakukan antara pukul 03:00-05:00, yang dalam rentang waktu tersebut aktifitas populasi spesies yang lain rendah (unpublished).

Tiga spesies Anopheles positif sporozoit $P$. vivax (An. maculatus, An. vagus, dan An. aconitus) terdapat ciri yang sama, yaitu populasi memiliki (1) rentang umur panjang; (2) kelimpahan tinggi (terkecuali An. aconitus); dan (3) antropofilikberdasarkan temuan sebelumnya (unpublished). Ketiga ciri dimiliki tiga spesies tersebut menentukan mengapa ketiganya menjadi kompeten vektor. Antropofilik merupakan syarat utama dan pertama untuk terjadinya kontak antara populasi nyamuk vektor dan Plasmodium sp. Besar peluang kontak nyamuk-Plasmodium bergantung dari kelimpahan populasi Anopheles sp., dalam arti semakin tinggi $\mathrm{Kn}$ populasi maka semakin besar peluang (risiko) anggota populasi mendapat infeksi Plasmodium sp. Plasmodium sp. yang menginfeksi nyamuk dapat melangsungkan siklus hidupnya secara lengkap (dari gametosit sampai ke tahap sporozoit/infektif) bilamana rentang umur nyamuk yang diinfeksi panjang-diindikasikan dengan proporsi nyamuk parous yang tinggi.

Temuan bahwa An. maculatus dan An. vagus di Desa Hargotirto positif sporozoit $P$. vivax membuktikan status vektor kedua spesies tersebut sama dengan temuan peneliti sebelumnya di desa lain di Kecamatan Kokap. Misalnya, An. maculatus di Desa Hargorejo tahun 2011 dinyatakan kompeten vektor karena positif CSP P. vivax, dengan IS 3,57\% (Widyastuti et al. 2013), dan An. vagus di Desa Hargorejo, Kalirejo, dan Hargowilis tahun 2005 juga disebut kompeten vektor karena positif CSP $P$. falciparum, dengan IS per desa, secara berurut $7,32 \% ; 20,0 \%$; dan $6,25 \%$ (Wigati et al. 2010). Dalam penelitian ini ditemukan IS An. maculatus lebih tinggi dari An. vagus (rasio $28 \%$ : 16,67\%), hal mengindikasikan bahwa $A n$. maculatus memiliki kompetensi vektoral lebih tinggi. Temuan ini lebih mengukuhkan status vektor An. maculatus yang dalam penelitian sebelumnya disebut vektor utama malaria di Kecamatan Kokap (NAMRU-2 1999). Besar IS yang lebih tinggi pada An. maculatus dapat dikaitkan dengan rentang umur populasi tersebut yang lebih panjang (rasio indeks Parous = 73,5\% : 67,1\%). Adapun temuan IS An. aconitus sebesar 100\% digunakan untuk menyatakan bahwa spesies ini kompeten vektor untuk $P$. vivax di Desa Hargomulyo, tetapi belum dapat menyimpulkan bahwa kompetensi vektoral spesies tersebut lebih tinggi dari An. maculatus (spesies dengan IS tertinggi di Desa Hargotirto; 28\%). Alasannya karena IS An. aconitus sebesar $100 \%$ tersebut diperoleh berdasarkan perhitungan satu sampel positif dari satu sampel diperiksa (besar sampel terbatas karena Kn populasi ditemukan sangat rendah $-<1 \%$ ). Sebaliknya, populasi An. balabacensis yang nihil sporozoit, belum dapat disimpulkan bahwa spesies ini tidak kompeten sebagai vektor malaria, dengan alasan (1) sebelumnya pernah dibuktikan sebagai spesies kompeten vektor malaria di Kecamatan Kokap karena positif CSP P. vivax (Adrial et al. 2000); (2) populasi memiliki $\mathrm{Kn}$ tinggi dan rentang umur panjang; dan (3) ada indikasi populasi bersifat antropofilik, ditandai dengan sampel yang ditemukan tidak ada yang berasal dari nyamuk beristirahat di kandang, melainkan diperoleh dari yang hinggap di manusia (penangkap nyamuk). Oleh karena anggota populasi An. balabacensis cenderung hinggap di tubuh penangkap di dalam maupun di luar rumah maka dilakukan penangkapan dengan metoda landing collection, meskipun metoda yang ditetapkan adalah resting collection. Besaran IS spesies dalam penelitian ini tidak diperbandingkan dengan besar IS dari temuan peneliti sebelumnya karena alasan adanya perbedaan lokasi, waktu maupun metode deteksi sporozoit yang digunakan. Metode deteksi sporozoit dengan PCR (Multiplex-PCR) yang digunakan dalam penelitian ini memiliki senstifitas dan spesifisitas lebih tinggi dari metode yang digunakan peneliti sebelumnya - ELISA (Mohanty et al. 2007; Hasan et al. 2009).

Hasil penelitian ini yang menunjukkan Desa Hargotirto dan Desa Hargomulyo terdapat perbedaan dalam hal jenis spesies vektor dan infektifitasnya (indeks sporozoit) berimplikasi pada penentuan upaya pengendalian vektor yang spesifik wilayah, terutama pengendalian pada nyamuk pra dewasa, karena ketiga spesies kompeten vektor tersebut memiliki perbedaan preferensi habitat perkembangbiakan. Menurut Sigit (2005) bahwa informasi tentang spesies vektor dan bionomiknya penting untuk pemahaman epidemilogis dan penentuan strategi pengendalian penyakit tular vektor (termasuk malaria). Oleh 
karena itu, diharapkan hasil temuan penelitian ini bermanfaat bagi stakeholder Kabupaten Kulon Progo untuk perencanaan secara tepat strategi pengendalian (pemilihan metode dan sasaran) dan alokasi sumber daya kegiatan pengendalian vektor maupun kegiatan lain terkait (misalnya edukasi ke masyarakat tentang potensi penularan dan upaya pencegahan di tingkat individu). Semua kegiatan pengendalian tersebut ditujukan untuk menurunkan jumlah atau menghilangkan fokus aktif (lokasi yang masih terjadi penularan setempat) dan jumlah kasus penularan setempat. Melalui pengendalian vektor yang tepat sasaran dan tepat metode diharapkan terjadi percepatan pencapaian eliminasi malaria di Kabupaten Kulon Progo, yakni kasus penularan setempat mencapai nol selama tiga tahun berturut (Kemenkes. 2009).

\section{KESIMPULAN}

Infektifitas spesies dan indeks sporozoit total Anopheles sp. DET dan DER berbeda secara signifikan. DET memiliki infektifitas spesiesspesies kompeten vektor malaria yang lebih banyak (An. maculatus dan An. vagus) dengan indeks sporozoit total wilayah yang lebih tinggi, hal ini menandakan DET memiliki risiko lebih tinggi mengalami intensitas penularan malaria yang tinggi (menjadi wilayah endemis tinggi malaria) dibandingkan dengan DER. Temuan penelitian berimplikasi pada perlunya skala prioritas tinggi alokasi sumber daya dan strategi pengendalian vektor yang spesifik wilayah bagi DET, tanpa mengabaikan DER yang juga berisiko terjadi penularan malaria akibat adanya Anopheles sp. kompeten vektor (An. aconitus).

\section{UCAPAN TERIMA KASIH}

Penghargaan dan terima kasih penulis sampaikan kepada Kepala BBPP-SDM Kementerian Kesehatan RI atas pemberian bantuan beasiswa pendidikan, termasuk biaya penelitian; penangkap nyamuk di Desa Hargotirto dan Hargomulyo yang telah membantu proses sampling nyamuk; Kepala Balai dan Kepala Laboratorium dan Teknisi di Laboratorium Biologi Molekular dan Laboratorium Entomologi
BBPPVRP Salatiga atas pendampingannya dalam pemeriksaan secara PCR untuk deteksi sporozoit Plasmodium sp. di nyamuk uji.

\section{DAFTAR PUSTAKA}

Adrial, Mardihusodo SJ, Tjokrosonto S, Atmosoedjono S. 2000. Penentuan status vektor malaria nyamuk Anopheles balabacensis (Diptera: Culicidae) di Kokap, KulonProgo, Daerah Istimewa Yogyakarta. Sains Kesehatan 13:89-98.

Asik, Purbadi IMY, Samad I, Kusumaningsih M, Theodora M, Intarti Y, Susasnto H, Laihad FJ, Worowijat, Rogayah H, Pramono B, Sambodo A, Hawley W, Hakim L, Paulus S, Izhar A. 2014. Pedoman Pengendalian Vektor Malaria. Jakarta: Ditjen. Pengendalian Penyakit dan Penyehatan Lingkungan.

Departemen Kesehatan [Depkes] RI. 2000. Kunci Bergambar Nyamuk Anopheles Dewasa di Jawa. Jakarta: Ditjen Pemberantasan Penyakit Menular dan Penyehatan Lingkungan Pemukiman.

Departemen kesehatan [Depkes] RI. 2003. Modul Entomologi Malaria. Jakarta: Ditjen Pengendalian Penyakit dan Penyehatan Lingkungan.

Dinkes. Kab. Kulon Progo. 2012. Profil Kesehatan Kabupaten Kulon Progo Tahun 2012. Wates.

Bangs MJ, Rusmiarto S. 2007. Malaria Vector Incrimination in Indonesia using CSP-ELISA from 1986 to 2007. U.S. Naval Medical Research Unit 2 (NAMRU-2). Jakarta. Unpublished report.

Barodji, Boewono DT, Sumardi. 2007. Fauna nyamuk, konfirmasi vektor dan beberapa aspek bionomik vektor malaria di daerah endemis malaria Kabupaten Pekalongan. Jurnal Ekologi Kesehatan 6:548-558.

Bass C, Nikou D, Blagborough AM, Vontas J, Sinden RE, Williamson MS, Field LM. 2008. PCR-based detection of Plasmodium in Anopheles mosquitoes: a comparison of a new high-throughput assay with existing methods. Malaria Journal 7:177. doi: http://dx.doi. org/10.1186/1475-2875-7-177.

Boewono DT. 2012. Indikator Entomologi sebagai Variabel Epidemiologi dan Penentuan Strategi Pengendalian Vektor.Didalam:OrasiPengukuhan Profesor Riset Bidang Biologi Lingkungan. Jakarta: Badan Penelitian dan Pengembangan Kesehatan Kementerian Kesehatan RI.

BPS Kulon Progo. 2012. Kecamatan Kokap dalam Angka 2012. Wates: Badan Pusat Statistik Kabupaten Kulon Progo. 
Hasan AU, Suguri S, Sattabongkot J, Fujimoto C, Amakawa M, Harada M, Ohmae H. 2009. Implementation of a novel PCR based method for detecting malaria parasites from naturally infected mosquitoes in Papua New Guinea. Malaria Journal 8:182. doi: http://dx.doi. org/10.1186/1475-2875-8-182.

Kec. Kokap. 2013. Profil Kecamatan Kokap Tahun 2013. Kecamatan Kokap. Kabupaten Kulon Progo.

Kemenkes. 2009. Keputusan Menteri Kesehatan R.I. Nomor 293/Menkes/SK/IV/2009 tentang Eliminasi Malaria di Indonesia. Jakarta: Mentrian Kesehatan.

Kemenkes. 2011. Buku Saku Menuju Eliminasi Malaria. Jakarta: Direktorat PPBB, Ditjen PP dan PL, Kementerian Kesehatan RI.

Kirnowardoyo S, Pitojo PD, Asfarain A, Situmeang RK, Zubaedah S, Riyanti F, Paulus S, Renny M. 2007. Vektor Malaria di Indonesia. Jakarta: Depkes. RI. Direktorat Jenderal Pengendalian Penyakit dan Penyehatan Lingkungan.

Mahapatra NNS, Marai MR, Ranjit SK, Parida DP, Hansdah RK, Hazra, Kar SK. 2006. Detection of Plasmodium falciparum infection in Anopheles Mosquitoes from Keonjhar District, Orissa, India. Journal of Vector Borne Diseases 43:191-194.

Mardihusodo SJ. 1999. Malaria: Status kini dan pengendalian nyamuk vektornya untuk abad XXI. Di dalam: Pidato Pengukuhan Jabatan Guru Besar Pada Fakultas Kedokteran Universitas Gadjah Mada. Yogyakarta: UGM.

Mohanty A, Kar P, Mishra K, Singh DV, Mohapatra N, Kar SK, Dash AP, Hazra PK. 2007. Multiplex PCR assay for the detection of Anopheles fluviatilis species complex, human host preference, and Plasmodium falciparum sporozoite presence, using unique mosquito processing method. The American Journal of Tropical Medicine and Hygiene 76:837-843.

Msugh-Ter MM, Gbilekaa VC, Nyiutaha IG. 2014. Sporozoite infection rates of female Anopheline mosquitoes in Makurdi, an endemic area for Malaria in Central Nigeria. Journal of the Entomological Research Society 2:103-115.

Murhandarwati EE, Fuad A, Nugraheni MDF, Suyanto S, Wijayanti MA, Widartono BS, Chuang TW. 2014. Early malaria resurgence in pre-elimination areas in Kokap Subdistrict, Kulon Progo, Indonesia. Malaria Journal 13:130. doi: http://dx.doi.org/10.1186/1475-2875-13-130.

Murti B. 2013. Desain dan Ukuran Sampel untuk Penelitian Kuantitatif dan Kualitatif di Bidang Kesehatan. Yogyakarta: UGM Press.

NAMRU-2. 1999. Post War II Locations of malaria vector's in Indonesia. Jakarta: Naval Medical Research Unit.
O’Connor CT, Soepanto A. 1999. Kunci Bergambar Nyamuk Anopheles Dewasa di Indonesia. Jakarta: Departemen Kesehatan R.I. Direktorat Jenderal Pemberantasan Penyakit Menular dan Penyehatan Lingkungan Pemukiman.

Patsoula E, Spanakos G, Sofianatou D, Parara M. 2003. A single-step, PCR-based method for the detection and differentiation of Plasmodium vivax and $P$. falciparum. Annals of Tropical Medicine \& Parasitology 97:15-21. doi: http:// dx.doi.org/10.1179/000349803125002535.

Reid JA. 1968. Anopheline Mosquitoes of Malaya and Borneo. Kuala Lumpur: Government of Malaysia.

Service MW, Townson H. 2002. The Anopheles vektor. In: Warrel DA, Gilles HM (Eds.), Essential Malariology $4^{\text {th }}$ ed. pp. 59-84. London: Oxford University Press Inc.

Sigit SH. 2005. Bioekologi Vektor dan Reservoir: Arti Pentingnya dalam Epidemiologi dan Pengendalian Penyakit. Jakarta: Simposium Nasional Vektor dan Reservoar Penyakit.

Snow RW, Gilles HM. 2002. The epidemiology of malaria. In: Warrel DA, Gilles HM (Eds.), Essential Malariology $4^{\text {th }}$ Ed. pp. 85-106. London: Oxford University Press Inc.

Szumilas M. 2010. Explaining odds ratios. Journal of the Canadian Academy of Child and Adolescent Psychiatry 19:227-229.

Theodolfi R. 2011. Studi Kompetensi dan Kapasitas Vektorial Anopheles vagus dan Anopheles barbirostris sebagai Vektor Malaria di Kelurahan Oesao Kabupaten Kupang. Tesis. Yogyakarta: Universitas Gadjah Mada.

Widyastuti U. 2001. Kompetensi Vektorial An. aconitus Donitz (Diptera: Culicidae) di Kecamatan Borobudur. Tesis. Yogyakarta: Universitas Gadjah Mada.

Widyastuti U, Boewono DT, Widiarti, Supargiyono, Satoto TBT. 2013. Kompetensi vektorial Anopheles maculatus Theobald di Kecamatan Kokap, Kabupaten Kulon Progo. Media Penelitian dan Pengembangan Kesehatan 23:47-56.

Wigati RA, Mardiana AY, Mujiono. 2006. Inkriminasi nyamuk An. vagus Donitz 1902 (Diptera: Culicidae) sebagai vektor malaria di Kecamatan Kokap, Kabupaten Kulonprogo, DIY. Sains Kesehatan 19:503-516.

Wigati RA, Mardiana, Mujiyono, Alfiah S. 2010. Deteksi protein circum sporozoite pada spesies nyamuk $A n$. vagus tersangka vektor malaria di Kecamatan Kokap, Kabupaten Kulon Progo dengan Uji Enzyme-Linked Immunosorbent Assay (ELISA).MediaLitbang Kesehatan XX:118-123.

Wilson DB. 2011. Calculating Effect Sizes. Tersedia di: www.campbellcollaboration.org [diakses 7 April 2015]. 